\title{
MOBILIDADE URBANA NO SISTEMA CICLOVIÁRIO DA AVENIDA CAETANO ÁLVARES
}

\author{
URBAN MOBILITY AT BYCICLE PATH SYSTEM OF \\ ENGENHEIRO CAETANO ÁLVARES AVENUE
}

\author{
ROSIANI VICTAL \\ Arquiteta e Urbanista graduada pela Universidade Presbiteriana Mackenzie \\ victalconsultoria@gmail.com
}

\begin{abstract}
RESUMO
O presente artigo visa estudar o traçado da ciclovia da Avenida Caetano Álvares, na Zona Norte da cidade de São Paulo, que faz parte do sistema cicloviário recentemente implantado pela gestão municipal. O objetivo é analisar questões como a segurança dos usuários e a continuação do traçado desta ciclovia para que a mesma sirva de ligação entre pontos estratégicos da cidade.
\end{abstract}

Palavras-chave: Mobilidade urbana; Ciclovias; Ciclofaixas; Segurança; Trajeto seguro

\begin{abstract}
This article aims to analyse the bike path route of Engenheiro Caetano Alvares Avenue, in the northern region of São Paulo City, which is part of the bike path system recently implemented by the city authorities. The target is to analyze issues such as the safety of users and the continuation of the route of this bike path so that it may serve as a link between strategic points of the city.
\end{abstract}

Keywords: Urban Mobility; Bike Paths; Bike Lanes; Safety; Safe Path 


\section{INTRODUÇÃO}

Muito se tem feito em relação a aumentar a mobilidade urbana através da bicicleta na cidade de São Paulo. É bem verdade que a recente gestão municipal tem trabalhado no sentido de dar à cidade de São Paulo essa opção de mobilidade ao trânsito dominado pelos veículos motorizados, através de seus esforços em implantar quilômetros de ciclovias e ciclofaixas.

Entretanto, a implantação do modal nem sempre tem seguido um modelo; por questões de espaço físico. A ciclofaixa, que possui um desenho padrão escolhido pela CET, acaba se limitando, em alguns pontos de sua rede, a uma estreita faixa vermeIha na lateral de uma via de grande velocidade, colocando em risco a vida de seus usuários, ou até desestimulando seu uso. A promoção do uso da bicicleta, por meio da implantação da rede cicloviária (incluindo estacionamentos de bicicletas, ciclovias, ciclofaixas) deveria ser feita através de caminhos seguros e isso inclui o fato de que seu traçado precisa ter larguras mínimas afim de assegurar proteção aos ciclistas.

Mas como garantir essa segurança? De acordo com o 17.o. Congresso Brasileiro de trânsito, ocorrido em setembro de 2009 em Curitiba, alguns técnicos entendem que o espaço totalmente segregado é a melhor opção. No entanto, percebe-se que ciclistas mais experientes preferem compartilhar a via com os demais veículos, ou usar a ciclofaixa, posto que ela Ihes permitiria um acesso mais direto aos diversos pontos da cidade. A ciclovia, apesar de mais segura, seria uma infraestrutura mais difícil e mais cara de ser implantada, por falta de espaços disponíveis. No caso da ciclofaixa, ela poderá existir em "sobras" existentes no sistema viário.

As faixas de tráfego urbano têm em geral uma largura de 3,00 a 3,50m de largura, com algumas diferenças para mais ou para menos, dependendo da via (de acordo com o documento acima, já foram observadas larguras com 2,60 ou 4,00, no caso de destinação de espaço preferencial para circulação de coletivos junto ao meio fio, por exemplo). Assim sendo, muitas vezes, a ciclofaixa será implantada na "sobra" de viário ao passo que para ciclovia, haverá a necessidade de readequar a largura das faixas do tráfego motorizado, promover a correção de bueiros e sarjetas e guias rebaixadas, tornando essa, uma opção mais cara.

Portanto, como ofertar para a cidade um modo de transporte que seja ao mesmo tempo seguro e não poluente, com caminhos que facilitem a vida do ciclista e fique viável financeira e socialmente para a administração municipal? 
Como menciona Jan Gehl, em seu livro "Cidade para Pessoas", é preciso haver um "convite para pedalar", o que em algumas cidades, para ele, está longe de ser convincente. Isso por que, em geral, a infraestrutura ciclística oferecida é de trechos desconectados entre si. Também para o autor, a segurança no trânsito é crucial para a criação de condições para o tráfego de bicicletas. Este "convite" seria, não só poder levar a bicicleta em metrôs, ônibus, combinando assim o modal com outros meios de transporte público, mas ofertar ciclovias protegidas por meio fios e carros estacionados por exemplo. A segurança nos cruzamentos também precisa ser verificada, pois boa visibilidade nos cruzamentos é essencial. Outros fatores que podem ser considerados convites ao pedalar são as características físicas adequadas, como por exemplo sombreamento (para compensação do calor gerado pela atividade física), pavimentação uniforme, largura suficiente, a previsão de locais de parada do ciclista como guias rebaixadas, rampas de acesso com declividade adequada. (ITDP - Instituto de Políticas de Transporte e Desenvolvimento, 2015).

Há também a questão da educação e "cultura" da bicicleta. Segundo Jan Gehl:

\footnotetext{
"Quanto mais bicicletas, mais atenção o motorista deverá ter, além de ficar constantemente alerta. Há um considerável efeito positivo quando o tráfego de bicicletas atinge certa " massa crítica".

“...É necessário que bicicletas tenham espaço suficiente para que não sejam empurradas ou fiquem aglomeradas. As ciclovias de Copenhague variam, na largura, entre 1, 7 a 4 metros, sendo que 2,5 m é o mínimo recomendado." (GEHL, 2013: 186)
}

Vamos verificar o desenho padrão escolhido pela CET e se este é seguido em um trecho do sistema cicloviário da cidade, na Zona Norte de São Paulo.

\section{MATERIAIS E MÉTODOS}

A rede cicloviária escolhida, se encontra na Zona Norte, e para efeito de análise, a área de estudo será o traçado da ciclovia da Avenida Engenheiro Caetano Alvares, cujas características de desenho fizeram parte do diagnóstico sobre Infraestrutura Verde Azul do trabalho entitulado "Trilha Norte-Sul", desenvolvido na disciplina AU-853 - Desenho Ambiental, do Curso de Pós-Graduação da FAU-USP, no $1^{\circ}$ semestre de 2016. Haverá um levantamento fotográfico de alguns de seus pontos para que seja verificado se seu traçado proporciona proteção ao uso da bicicleta. A figura 1, que demonstra os trechos do sistema na Zona Norte. 


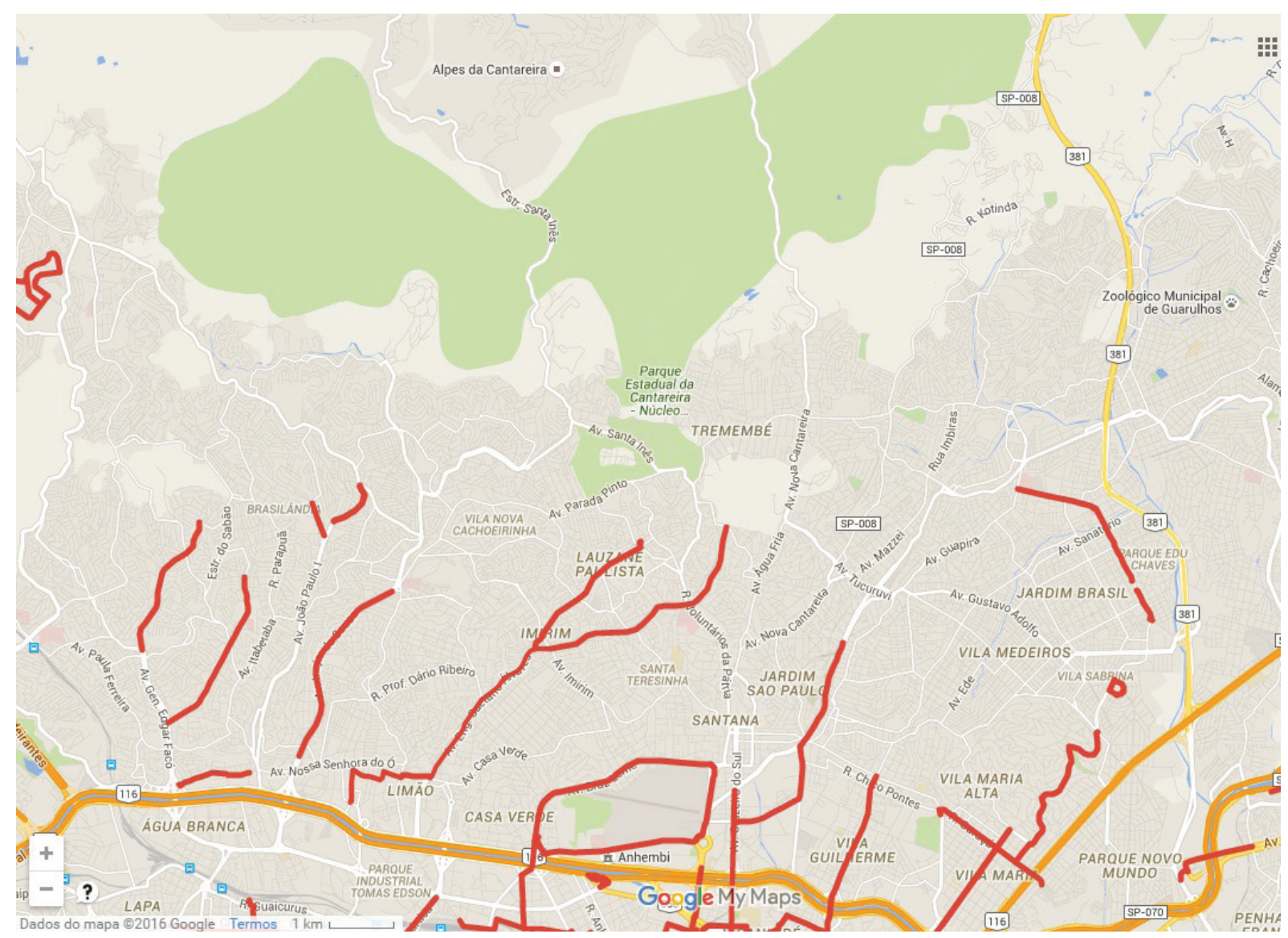

Figura 1 - Mapa do Sistema cicloviário da Zona Norte de São Paulo. Fonte: Google Maps

\section{SISTEMA CICLOVIÁRIO DE SÃO PAULO - SURGIMENTO}

De acordo com o texto do $18^{\circ}$. Congresso Brasileiro de Transporte e Trânsito, ocorrido no Rio de Janeiro em outubro de 2011, a legislação que é voltada ao uso da bicicleta data da década de 70 , quando já se promulgavam leis visando à implantação de infraestrutura para sua utilização. A Lei 10.907, foi sancionada em 1990 e dispõe sobre a obrigatoriedade de demarcação de ciclofaixas nas avenidas de acesso a parques e espaços para ciclovias em novas avenidas. Essa lei, foi regulamentada pelo decreto 34.854 , de 1995. O decreto institui que novos projetos de avenidas com construção de pontes e serviços de alargamento, estreitamento e retificação do sistema viário e calçadas serão precedidos de estudo de viabilidade física e socioeconômica para implantação de ciclovias. Em 2007, sanciona-se a lei 14.266, sobre a criação do Sistema Cicloviário de São Paulo, e institui uma rede formada por ciclovias, ciclofaixas, faixas compartilhadas e rotas operacionais de ciclismo, bem como locais para estacionamentos desse veículo e sua integração com o transporte coletivo. Logo após, surge 
a Lei Federal da política Nacional de Mobilidade Urbana (12.587, de 2012), que dava prioridade dos modos de transporte não motorizados sobre os motorizados e finalmente, o Plano Diretor Estratégico (Lei Municipal 16.050, de 2014) que tem o sistema Cicloviário de São Paulo como sua parte integrante.

Também podemos citar, no ciclo evolutivo do sistema cicloviário de São Paulo, o Processo Participativo do Plano de Mobilidade(2014 a 2015): Um grupo de trabalho Intersecretarial instituído por meio da Portaria n.o.376, para desenvolver o processo de construção do Plano de Mobilidade, sendo coordenado pela Secretaria Municipal de Transportes. Houve o processo participativo da população, em reuniões do Conselho Municipal de Transporte e Trânsito e a consequente elaboração do documento "Plano de Mobilidade de São Paulo-Modo Bicicleta", que especifica diretrizes, metas e ações para o sistema cicloviário. Ainda está prevista para 2016, a elaboração dos planos regionais e de bairro, que serão a oportunidade de estabelecer redes complementares à prevista no Plano de Mobilidade.

\section{EVOLUÇÃO DO USO DA BICICLETA NA CIDADE DE SÃO PAULO}

Segundo texto do $18^{\circ}$ Congresso Brasileiro de Transporte e Trânsito (2011) a utilização da bicicleta vem apresentando acréscimos desde 1977. De acordo com uma pesquisa feita pela Companhia do Metropolitano de São Paulo-Metrô, em 2007, eram feitas 150 mil viagens diárias de bicicletas, representando $0,6 \%$ do total de viagens do município. Regiões como a Sul, sudeste e Leste tiveram um aumento considerável do uso desse meio de transporte. A Zona Norte, que compreende a área de estudo, mesmo tendo uma topografia acidentada, também apresentou um número crescente de viagens/dia. Os bairros que compõem as subprefeituras dessa região, apresentavam em 1997, 8.725 viagens/dia. Em 2007, esse número passou para 26.749 viagens/dia. A figura 2 demonstra as regiões onde houve aumento significativo do uso da bicicleta, segundo a pesquisa de Origem-Destino: 


\section{7}

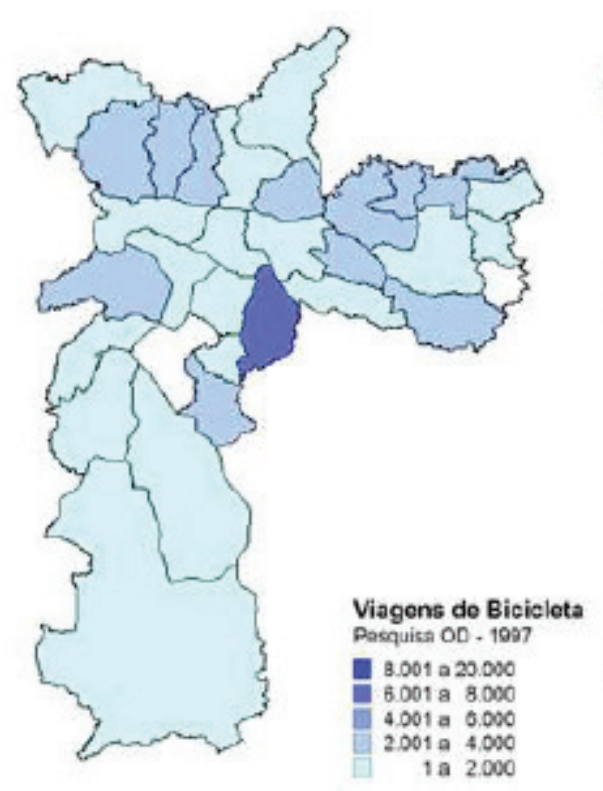

2007

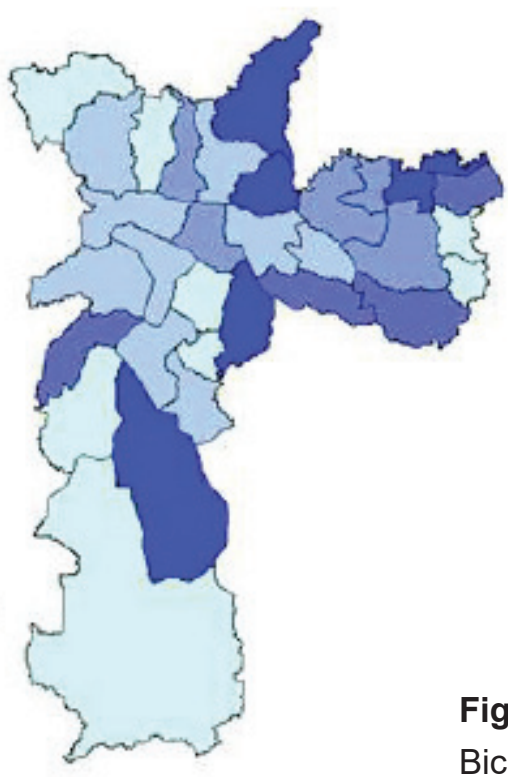

Figura 2 - Aumento do Uso da Bicicleta-Subprefeituras-MSP

Ainda, mais recentemente, foi publicada no "sítio" da Prefeitura de São Paulo, em setembro de 2014, pela Secretaria Executiva de Comunicação, a notícia de que "o número de paulistanos que utilizam a bicicleta todos os dias como meio de transporte cresceu 50\% em 2014 em comparação a 2013, de acordo com a Pesquisa de Mobilidade Urbana, feita pelo Ibope..."

De acordo com a notícia, em 2013 o número de ciclistas era de 174,1 mil moradores da cidade enquanto em 2014, esse número subiu para 261 mil, aproximadamente.

Isso vem demonstrar que a oferta de infraestrutura para essa modalidade de transporte, tem influído no aumento do uso deste veículo na cidade de São Paulo.

\section{DIRETRIZES DA REDE CICLOVIÁRIA E TIPOLOGIAS DE TRATAMENTO DO SISTEMA CICLOVIÁRIO:}

De acordo com o Plano de Mobilidade de São Paulo-Modo Bicicleta, o sistema Cicloviário é composto de Rede Cicloviária Estrutural (implementação de infraestrutura viária para a circulação de bicicletas; sistema de compartilhamento de bicicletas; estacionamento de bicicletas e ações e programas complementares à infraestrutura cicloviária). 
Essa rede, deve atender às diretrizes de conectividade, ou seja, conectar origens e destinos de viagens para que o ciclista possa fazer uso eficiente da rede. Também deve possibilitar a conexão do centro aos bairros(chamadas de ligações perimetrais e radiais); linearidade, que é neste sentido, a busca do trajeto de menor distância possível de viagem; intermodalidade, ou conexão com os terminais e estações de transporte coletivo e seus pontos nodais(com implantação de bicicletários nestes locais); funcionalidade relativa à hierarquia viária e incorporação de novas vias: $A$ primeira é que, na hierarquia viária, as vias de função estrutural são objeto de inclusão de infraestrutura cicloviária e a última, pressupõe-se de que todas as vias estruturais construídas ou alargadas deverão prever a implantação de estrutura cicloviária.

Temos as seguintes tipologias de tratamento cicloviários:

Ciclovias: Pista de uso exclusivo de bicicletas e outros ciclos. Segregação física do tráfego lindeiro motorizado ou não, com sinalização viária, podendo ter piso diferenciado no mesmo plano da pista de rolamento ou no nível da calçada. Ela pode ser de duas formas: Unidirecional, com um único sentido de circulação ou bidirecional, com sentido duplo de circulação

Ciclofaixas: Uso exclusivo das bicicletas, com segregação visual do tráfego lindeiro, podendo ter piso diferenciado no mesmo plano da pista de rolamento. Também como as ciclovias, podem ser unidirecionais ou bidirecionais.

Ciclorrotas: Sinalização cicloviária específica em pista de rolamento compartilhada com os demais veículos. As características de volume e velocidade do trânsito na via possibilitam o uso de vários modos de transporte, conforme a figura 3.

\section{TIPOLOGIAS}

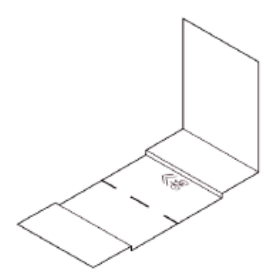

VIAS COMPARTILHADAS

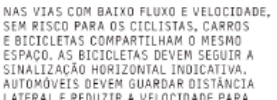

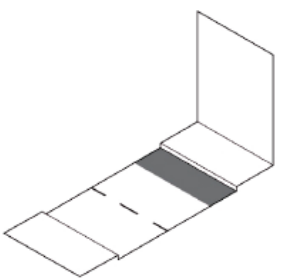

CICLOFAIXAS

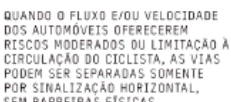

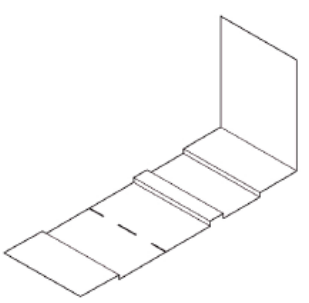

CICLOVIAS EM VIAS DE MATOR FLUXOES
OU VEDCCDADE. POR MOTIVOS ESEGURANCA, NERCESSGR AUTOMOVEIS E BICICLETAS.
ESTAS PODEM SER MURTAS. ESTAS PODEM SER MURETAS.
CATERTRS OU MESMD FAIXAS
Figura 3 - Tipologias do Sistema Cicloviário. Fonte: ITDP. Novembro de 2015 . 
Há ainda os tratamentos em calçadas, conhecidos como calçadas compartilhadas e partilhadas, prevista no CTB (Lei Federal 9.503 de 1997, Art. 59), a circulação de bicicletas nas calçadas é permitida se for "autorizada e sinalizada pelo órgão ou entidade com circunscrição sobre a via". Seria possível então, utilizar a calçada de duas formas na rede cicloviária: Compartilhada: onde o espaço comum para circulação de bicicletas, pedestres, cadeirantes seja devidamente sinalizado ou Calçada Partilhada: Exclusiva para circulação de ciclos sobre a calçada, com segregação visual do tráfego de pedestres, podendo ter piso diferenciado no mesmo plano, devidamente sinalizado. Seriam como as ciclofaixas, mas nas calçadas.

Também para análise, precisamos conhecer o desenho escolhido como padrão de ciclovia pela CET, indicado na figura 4 .

Segundo a CET, de preferência a ciclovia deve ser bidirecional, no lado esquerdo da via, usando a estrutura como meio de transporte, em ruas secundárias, não pode eliminar a faixa de rolamento e deve haver integração modal com transporte de média e alta capacidade.

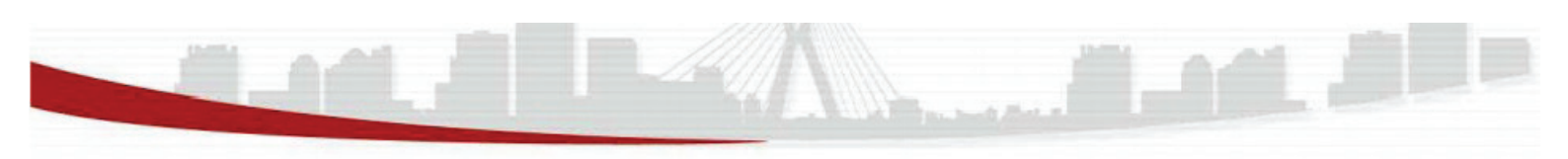

MODELO DE CICLOVIA

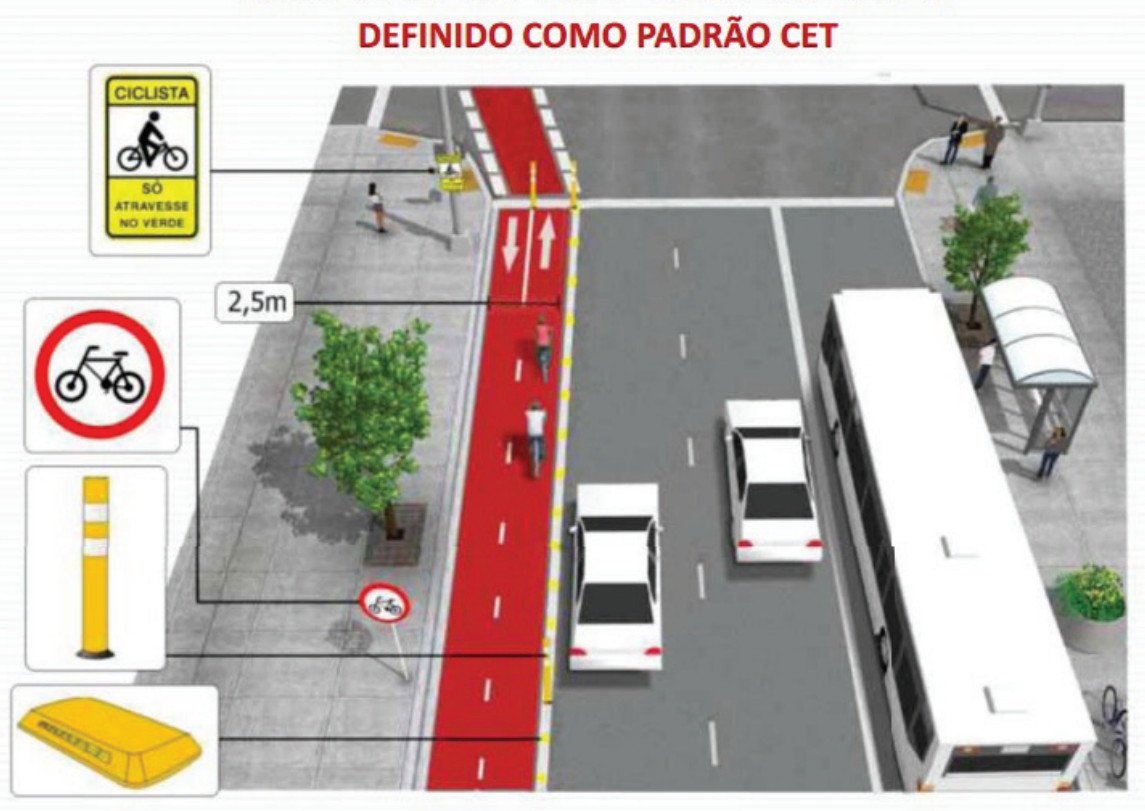

DESENHO DO MODELO ESCOLHIDO

Figura 4 - Modelo de Ciclovia Definido como padrão-Fonte: http://www.cetsp.com.br 
O modelo acima, no entanto, se refere somente ao desenho da ciclovia bidirecional, ou seja, é ideal que ela tenha $2,50 \mathrm{~m}$. Agora, como dimensionar a largura adequada das ciclofaixas unidirecionais? Qual seria a largura ideal para que o ciclista ainda tivesse a sensação de segurança? Essa pergunta foi respondida no $17^{\circ}$ Congresso Brasileiro de Trânsito:

"Outro importante ponto refere-se à largura das ciclofaixas unidirecionais. Ela não deve ser demasiadamente estreita, gerando aos ciclistas a sensação de insegurança, nem tampouco muito larga que favoreça o seu uso como ciclofaixa bidirecional, contribuindo para o aumento dos riscos de acidentes. Recomendamos ainda que as ciclofaixas tenham separação mínima de 0,20m do meio-fio para garantir o espaço da sarjeta e a passagem livre das águas pluviais em dias de chuva. Em vias com tráfego limitado a $50 \mathrm{~km} / \mathrm{h}$ deve-se manter um afastamento do tráfego geral através de duas faixas com 0,10m de largura, tendo ao centro espaço de 0,25m para que sejam implantados tachões refletivos. No entanto, caso

O espaçamento entre as duas faixas possa ser superior a 0,50 m já torna possível a criação de área "zebrada" entre as faixas contínuas, separando com marcas de canalização os espaços da circulação de ciclistas e dos motorizados. Assim, aumenta-se sensivelmente a segurança de tráfego para todos, ou seja, motorizados e não motorizados.

Uma vez garantidos tais dispositivos o espaço interno das ciclofaixas poderá ter um mínimo de $1,00 \mathrm{~m}$. Isto levando em consideração que o maior dos guidões de bicicleta fabricada em série no Brasil não excede a 0,65 m. Porém, recomenda-se que ciclofaixas unidirecionais tenham largura de 1,20 m. Entende-se, a partir das experiências realizadas, que ao se considerar 0,20m de largura mínima da sarjeta, acrescida dos $0,45 \mathrm{~m}$ do espaço ocupado pelas faixas separadoras e pelo tachão que a limita com o espaço do tráfego geral, tem-se como largura total na construção de uma ciclofaixa unidirecional a dimensão de 1,85m".(MIRANDA, et al., 2009)

Além dos quesitos já mencionados acima, que diz respeito às características de desenho, vejamos quais outros critérios torna a ciclovia, um "convite para pedalar". Através de vistorias feitas pelo Instituto de Políticas de Transporte e Desenvolvimento, entre os dias 05/10/2015 e 23/10/2015 em mais de $220 \mathrm{~km}$ da rede cicloviária de São Paulo, em todas as regiões, foram avaliados critérios sobre: sinalização hori- 
zontal, sinalização vertical, semáforos, tratamento de interseções, largura das faixas, segregação, pavimento, manutenção, posicionamento da ciclovia/faixa em relação à via, e atratividade do traçado para o ciclista. Com essas vistorias, foi possível obter uma avaliação e, por conseguinte, sugestões para a melhora do traçado/sistema, como um todo, não só o quesito segurança. A seguir, veremos cada recomendação sobre os critérios acima supracitados.

Sinalização horizontal; vertical e semáforos: É importante que o posicionamento, mensagens sejam de fácil leitura, visíveis, que a altura e o tipo sejam adequados. Os semáforos para bicicletas devem ser posicionados de forma antecipada em relação aos cruzamentos. As travessias de ciclistas também devem ser indicadas antecipadamente e com boa visibilidade, conforme figura 5 .

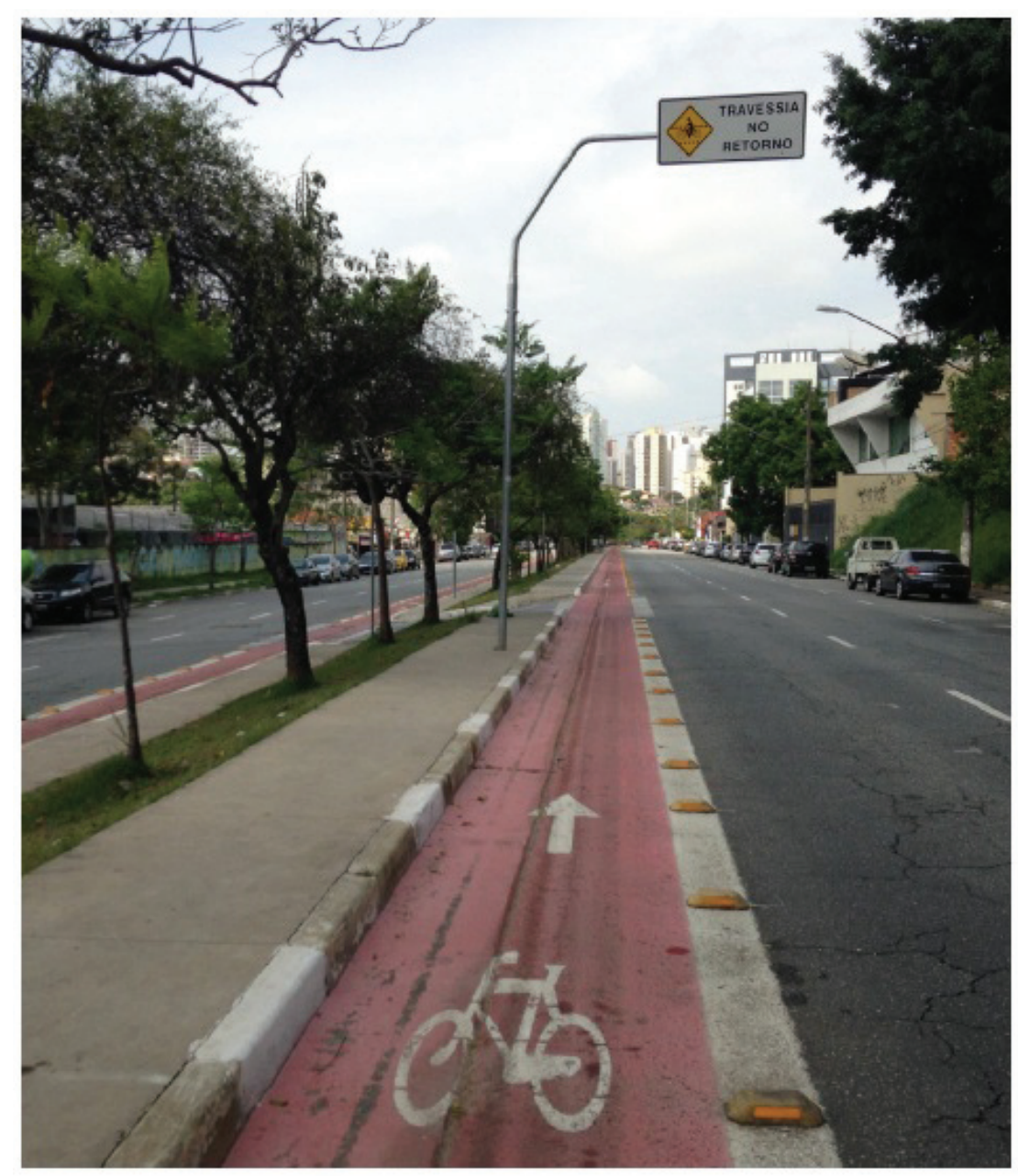

Figura 5 - Sinalização horizontal e Vertical de Ciclovia. Fonte: ITDP. 2015. 
Quanto à sinalização Vertical: Placas R-24a; A-30a (trânsito de ciclistas) e A-26a (sentido único) ou A-26b (sentido duplo). O ITDP recomenda que as placas A-30a e A-26 (a ou b) sejam colocadas junto às placas R-24a, de regulamentação do sentido da via por conta da melhor visibilidade, uma vez que os condutores já estão acostumados a visualizar este tipo de informação ao se depararem com o cruzamento de vias unidirecionais.

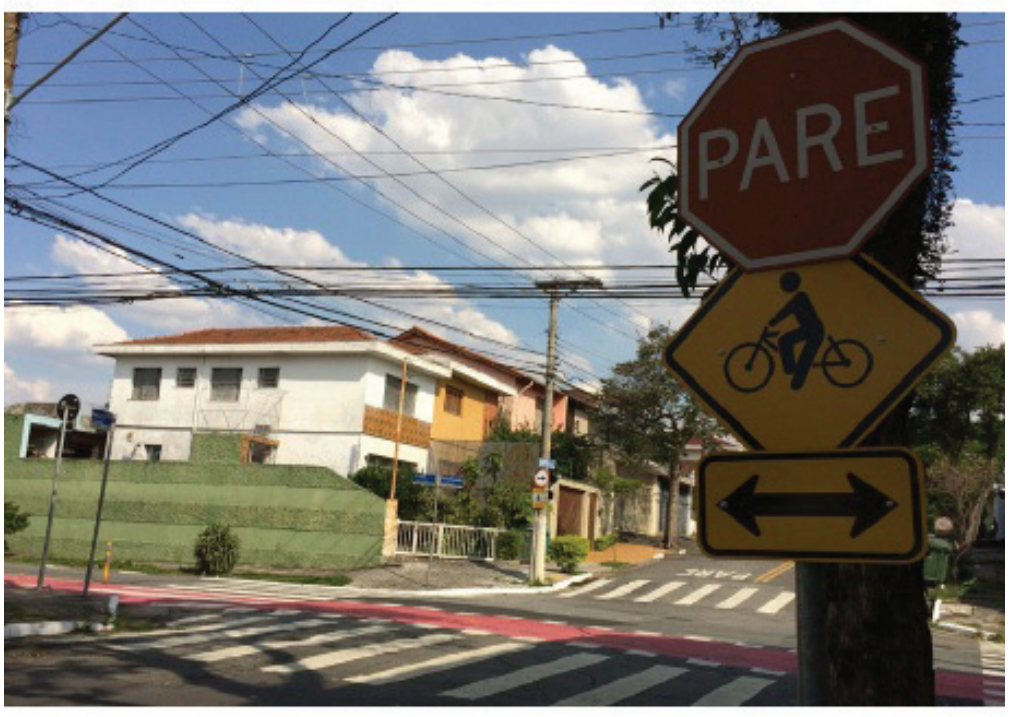

Placas A-30a e A-26a antecipadas em relação ao cruzamento e placa R-24a postecipada Av. Piassanguaba x R. Guatás, Zona Sul
Figura 6 - Sinalização Vertical: Localização. Fonte foto: ITDP 2015.

Tratamento de Interrupções: são muitas as possibilidades de interrupções na cidade. Como pontos de ônibus, áreas de embarque e desembarque de escolas, por exemplo. E também algumas possibilidades de soluções. Se a infraestrutura cicloviária coincide com áreas de embarque e desembarque, o que tem sido feito, é a interrupção da ciclofaixa, acompanhada de sinalização de solo e sinalização vertical educativa. No entanto, essa interrupção será feita apenas quando as possibilidades de outras soluções estiverem esgotadas.

Segregação: A separação deve ser realizada de maneira adequada ao tipo de conflito da via. Por exemplo, há locais onde o trânsito de caminhões e ônibus é bastante intenso, ou ainda outros locais onde é carregado e constante. Em outros locais, as ciclofaixas foram implantadas no meio da pista, mas sem segregação física, o que ocasiona invasão de veículos em conversões. Pode-se estabelecer condições de separação com a elevação do canteiro central ou calçada, sinalização de canteiros centrais fictícios, elementos físicos como balizadores e mesmo estacionamento de veículos em perpendicular ou em paralelo, para proteção da faixa. Alguns exemplos de segregação seguem nas fotos a seguir: 


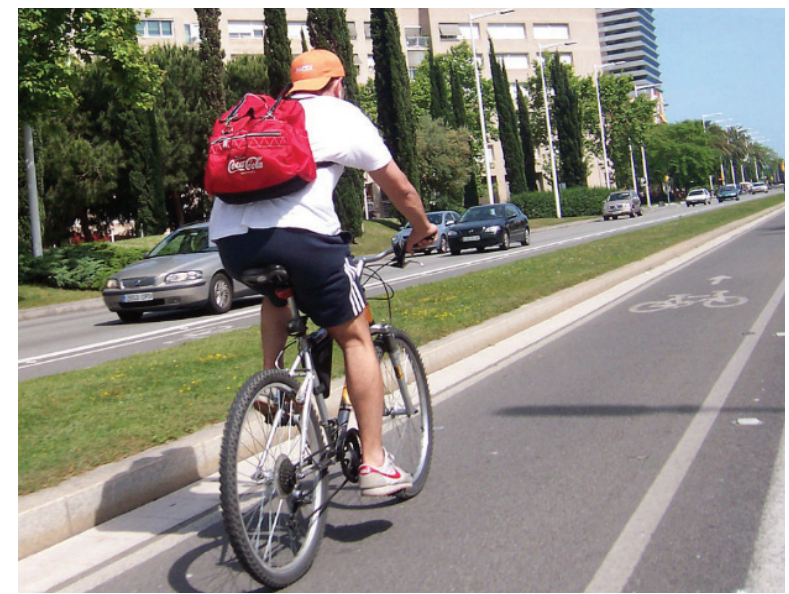

Figura 7 - ciclofaixa em Barcelona. Fonte: Wikipedia < https://pt.wikipedia.org/wiki/Ciclovia>
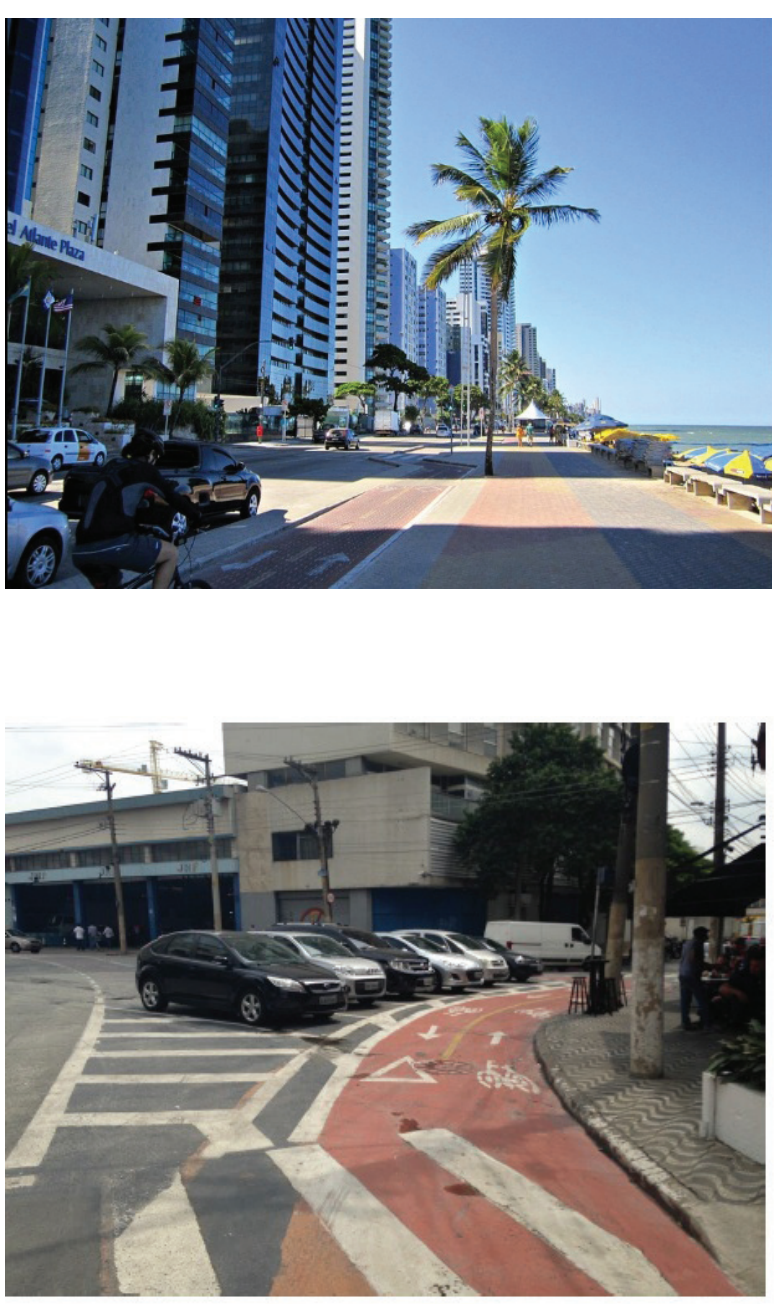

Ciclovia segregada com buffer (canteiro central fictício) e estacionamento de veículos perpedicular R. Rio Bonito, Centro

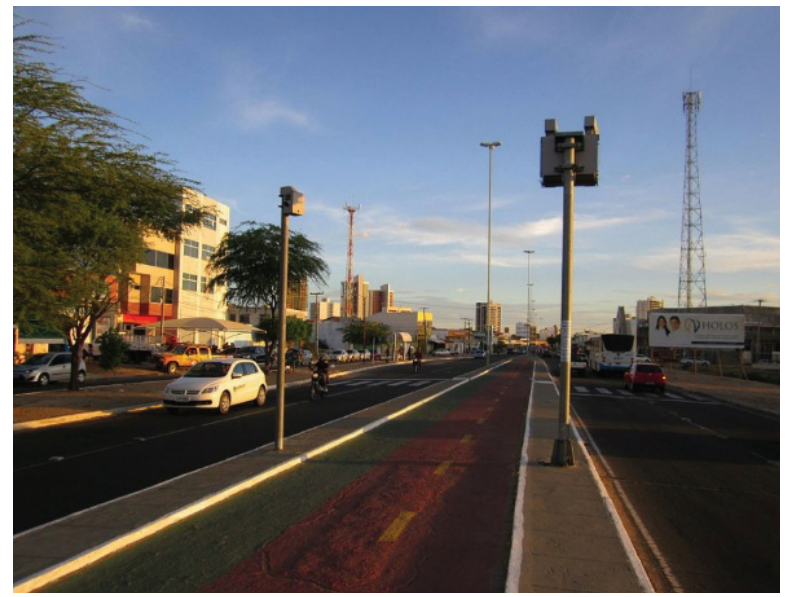

Figura 8 - Ciclofaixa em Petrolina. Fonte:

Wikipedia < https://pt.wikipedia.org/wiki/Ciclovia>

Figura 9 - ciclovia Praia de Boa Viagem, Pernambuco. Fonte: Wikipedia $<$ https://pt.wikipedia.org/ wiki/Ciclovia>

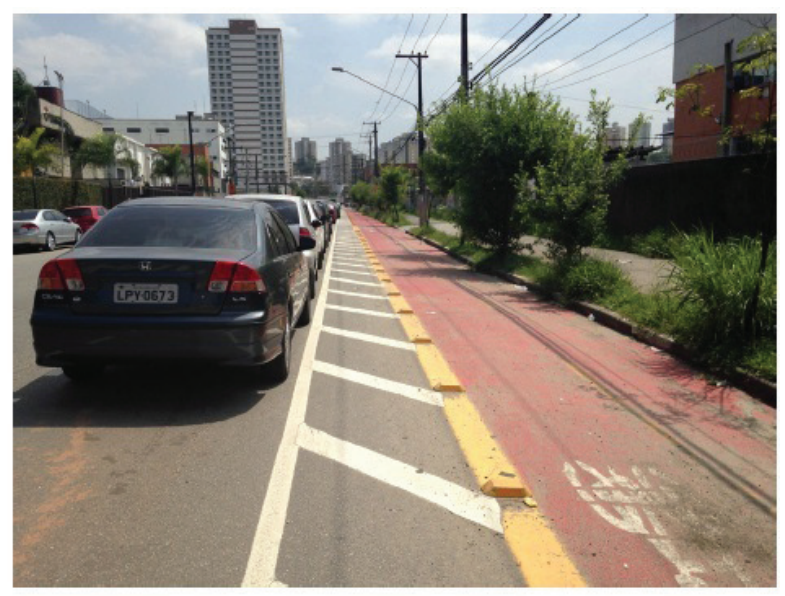

Ciclovia segregada com buffer (canteiro central fictício) e estacionamento de veículos em paralelo R. Maestro Gabriel Migliori, Zona Norte

Figura 10 - Segregação com "buffers" ou canteiros centrais fictícios. Fonte: ITDP, 2015. 
Pavimentação, manutenção, posicionamento da ciclofaixa em relação à via: $A$ avaliação feita pelo ITDP recomenda que haja um desenho sem desvios e livres de obstáculos, evitando curvas (para desviar de obstáculos como árvores, postes, caixas de inspeção, etc.), redução da frequência de paradas obrigatórias; desativação de locais de retorno e conversões de veículos motorizados à esquerda sempre que possível.

Deve haver uma coerência na linguagem, todas as cores utilizadas, bem como a sinalização e sentidos de circulação, além de que as larguras deverão ser constantes, com segregadores padronizados. Assim, todo e qualquer usuário pode entender o sistema, mesmo que não o utilize.

Atratividade do traçado ao ciclista: Características como boas condições físicas de implantação e manutenção, como por exemplo, a pavimentação uniforme, livres de buracos, elevações ou outros problemas; largura suficiente da faixa, guias rebaixadas e rampas de acesso também são importantes.

Sistemas de sinalização de destinos (conhecidos como wayfinding): centros de bairros, pólos geradores de viagens, bairros, estações, indicação onde há estrutura cicloviária, orientação dos melhores caminhos para o ciclista, pontos de interesse e de conexão.

O desenho cicloviário, quando possível ser feito em áreas arborizadas, por caminhos que passem por locais relevantes como praças e pontos culturais, onde haja conexão com centralidades, com iluminação e visibilidade suficientes, bem como a questão da segurança (trechos deveriam passar por áreas de uso misto, dotadas de fachadas ativas, de fácil acesso, com inclinação favorável) são características desejáveis para atração de ciclistas ao sistema cicloviário.

\section{O TRECHO DA AVENIDA CAETANO ÁLVARES COMO ÁREA DE ESTUDO}

A escolha do trecho da Avenida Caetano Álvares não foi feita por acaso. De acordo com o Boletim Técnico 50, da CET, uma análise dos dados da Pesquisa Origem e Destino 2007 do METRÔ realizada pela CET, identificou onde havia o maior número de viagens de bicicleta por motivo de trabalho, e as zonas que se destacaram foram: Leste (Jardim Helena/Itaim Paulista); Norte (Jardim Brasil/Jaçanã) e Sul (Grajaú/Cocaia). Todos esses locais tinham esta ocasião, mais de 5.000 viagens por dia. A pesquisa em questão contabilizou viagens que eram feitas totalmente por bicicle- 
tas, desconsiderando viagens onde esse modal entrou como modo complementar de transporte (MALATESTA, 2012)

Se considerarmos outro ponto específico da Zona Norte, a Avenida Inajar de Souza, temos também os dados do Instituto Ciclocidade, que faz contagem anual de ciclistas em diversos pontos da cidade de São Paulo. No ano de 2015, ela foi feita na altura do número 5.550 desta da avenida. O resultado, foi um número total de ciclistas de 1.350 em um período de 14 horas, uma média de 96,43 por hora. O que aponta para um intenso uso da via por motivo de deslocamento diário, segundo o Ciclocidade, a contagem nessa avenida fica atrás apenas das avenidas Faria Lima(1.941) e Paulista(2.112). De acordo com o mapa do sistema cicloviário já implantado na Zona Norte(Figura 1). A Avenida Caetano Álvares seria então, por ter sido analisada na temática "Trilha Norte-Sul" e ser na Zona Norte, a mais próxima do Jaçanã, onde a pesquisa Origem Destino, indica um número grande de viagens por bicicletas.

O trecho começa na Avenida Engenheiro Caetano Álvares próximo às Avenidas Mandaqui e Avenida Casa Verde. Recentemente, um novo trecho de ciclovia foi inaugurado, segundo o sítio da CET. Esse novo trecho faz a conexão com as ciclovias da Avenida Engenheiro Caetano Álvares e da Rua Coronel Mario de Azevedo, com percurso bidirecional, ao lado da calçada, no trecho carroçável, conforme mostra a figura abaixo:

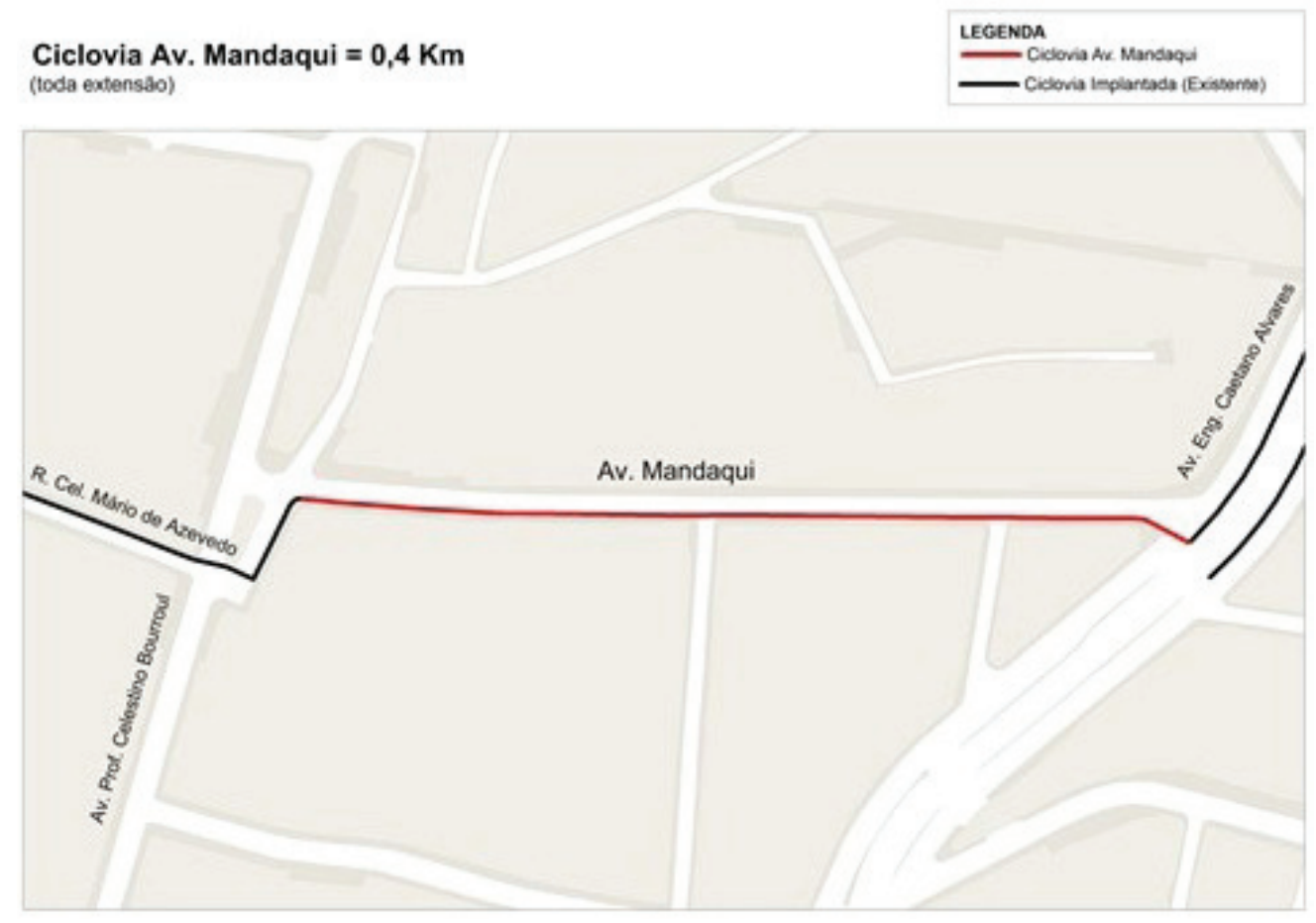

Figura 11 - Novo Trecho de Ciclovia na Zona Norte-Avenida Mandaqui. Fonte: CET. 
Analisando algumas fotos da ciclovia/faixa desta Avenida, já podemos notar alguns pontos críticos:

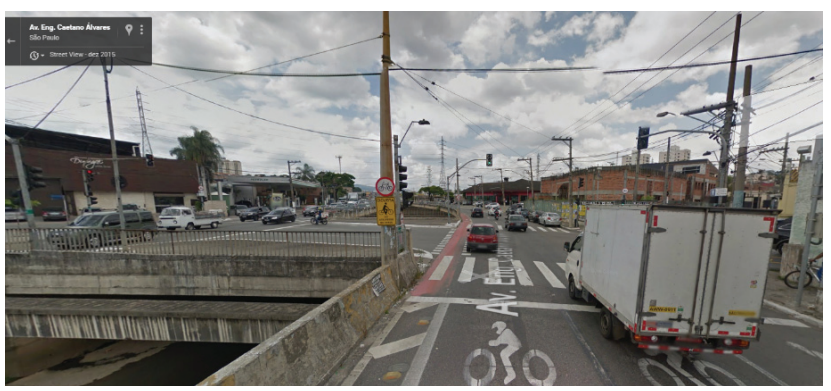

Figura 12 - Começo nada convidativo. Fonte: Google Maps. Acesso: 22/05/2016.

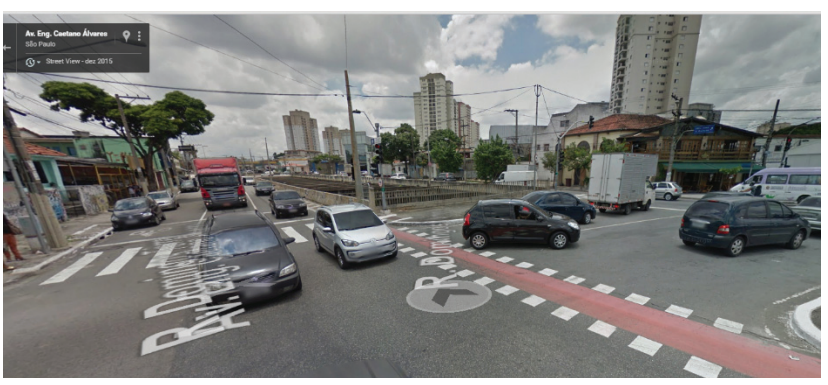

Figura 13 - Dividindo espaço com veículos que convergem à esquerda. Fonte: Google Maps

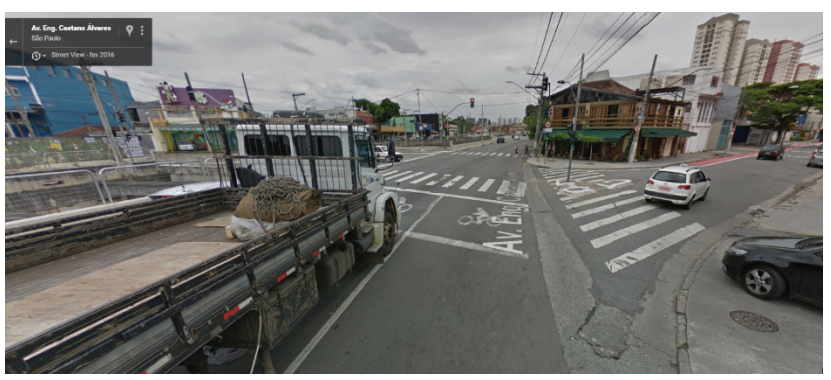

Figura 14 - Começo do novo Trecho na Avenida Mandaqui. Fonte Google Maps

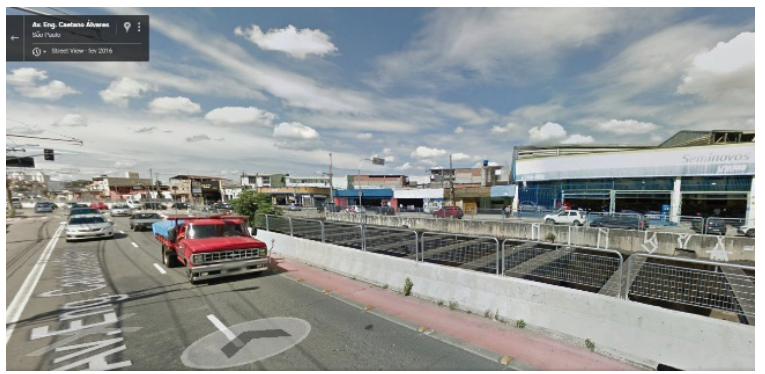

Figura 15 - Fonte Google Maps
Seu início não tem nenhum dos pontos discutidos sobre "convite a pedalar". Como podemos ver, essa avenida possui um trânsito pesado, com tráfego de caminhões e ônibus. A ciclofaixa neste ponto não está segregada nem mesmo com balizadores.

O ciclista se vê obrigado a dividir espaço com os veículos que convergem à esquerda, sem nenhum tipo de proteção. Assim como o começo da ciclofaixa da Avenida Engenheiro Caetano Álvares, o da Avenida Mandaqui também não tem conexão com nada em seu traçado, como podemos ver pela foto 15 . As figuras 16 e 17 nos mostram trecho da avenida Engenheiro Caetano Álvares nos dois sentidos da via.É possível notar a falta de segregação física, o que no caso desta via seria extremamente recomendável, haja vista que o ciclista fica vulnerável ao tráfego pesado de caminhões e ônibus. 


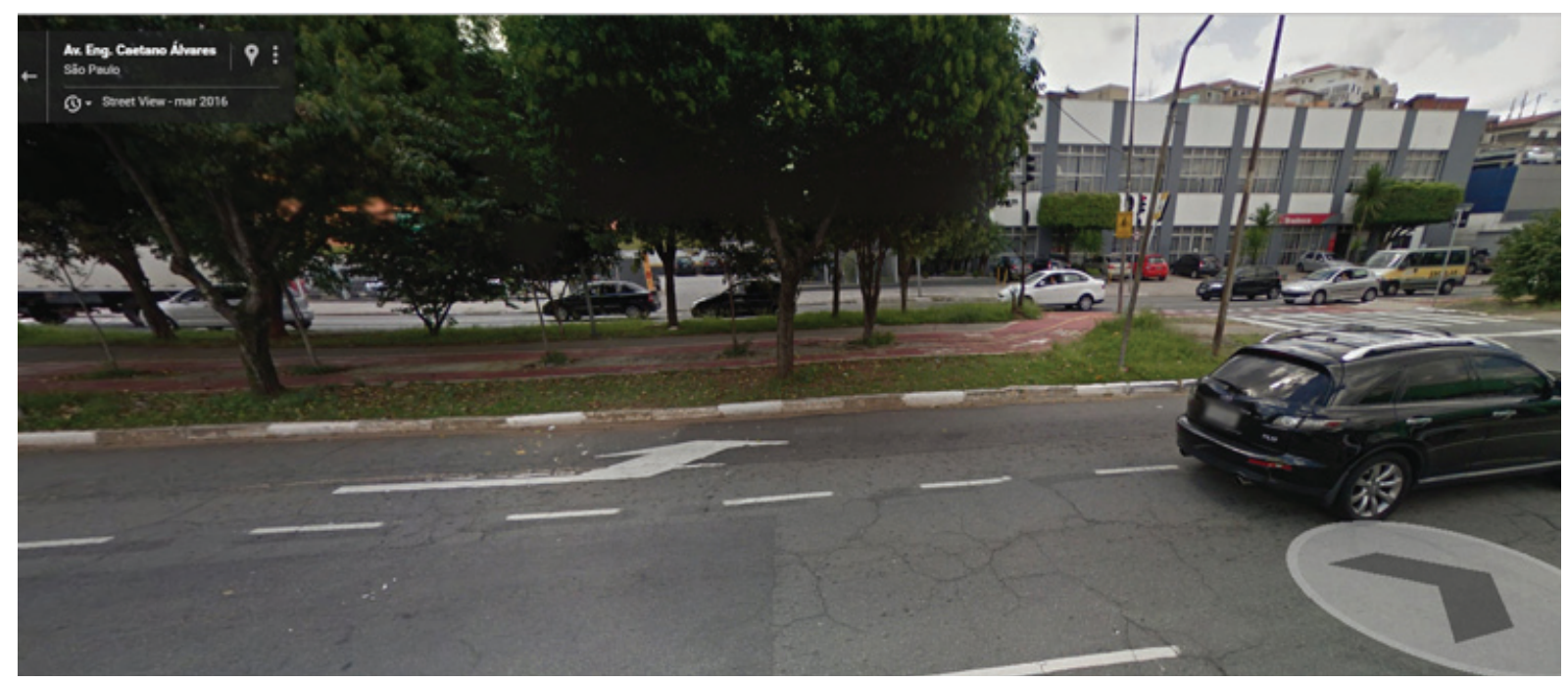

Figura 17 - Trecho próximo à Avenida Imirim. Árvores no caminho.

Fonte Google Maps. Acesso: 22/05/2016

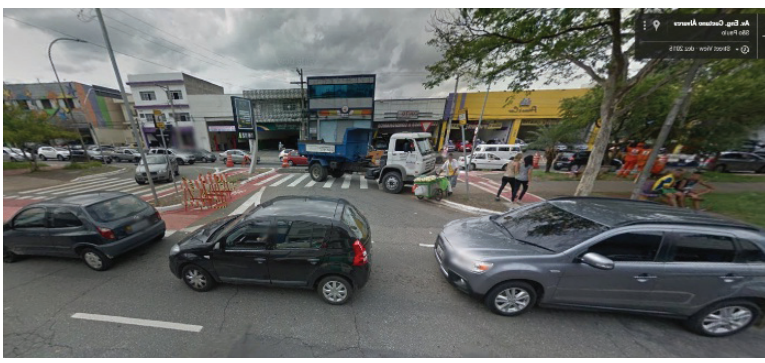

Figura 18 - Trecho Confuso

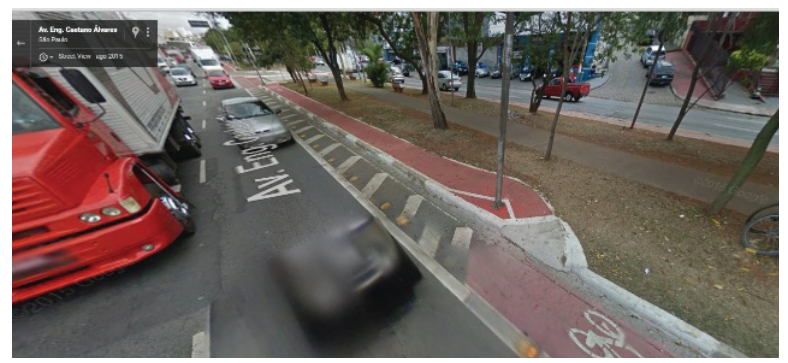

Figura 19 - Falta de Linearidade

$\mathrm{Na}$ altura da Avenida do cruzamento com a Avenida Imirim (Figuras 17, 18 e 19), nota-se a falta de linearidade e a confusão do traçado. Aqui, o mais indicado teria sido utilizar-se do canteiro central, alargando-o para que pudesse ser utilizado tanto por ciclistas e pedestres protegidos do trânsito. Isso daria ao traçado uma maior coerência e aumentaria a segurança do ciclista.

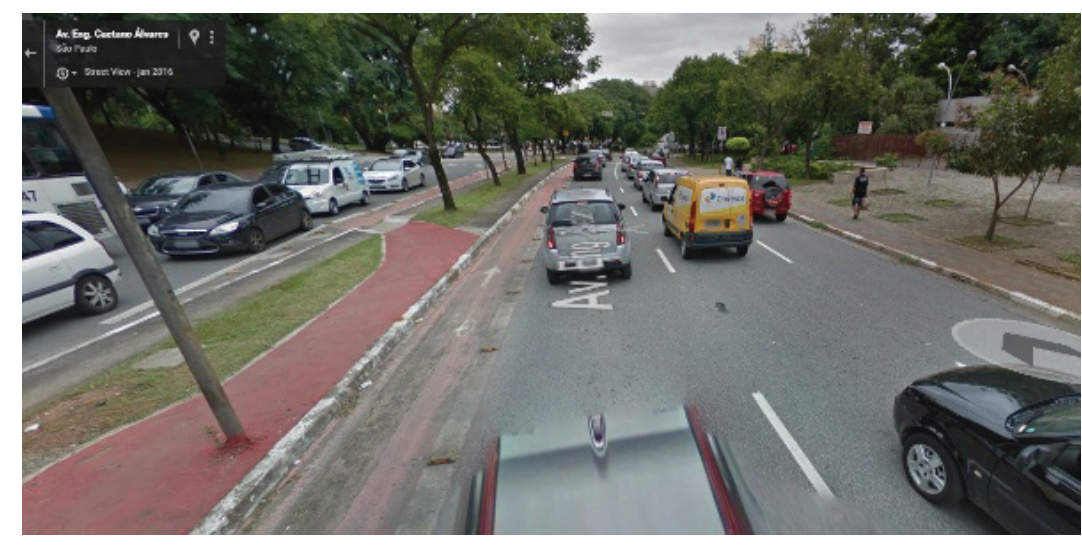

Figura 20 - Obstáculos

no caminho 


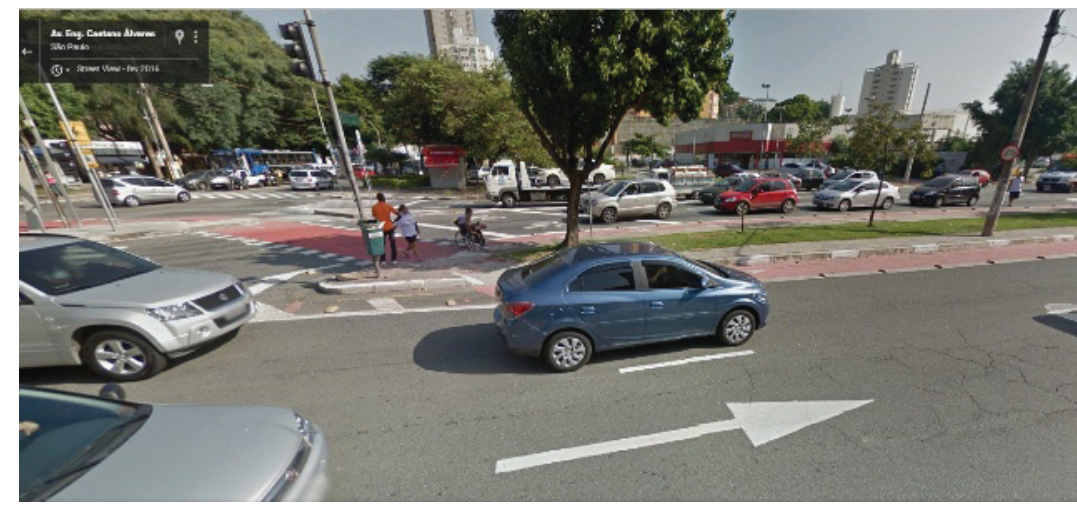

Figura 21 - Conflito com preferência pedestre/ciclista. Fonte fotos: Google Maps. Acesso 22/05/2016

Nas figuras 20 e 21, próximas ao trecho que cruza com a Avenida Voluntários da Pátria, novamente temos situações de desconforto e falta de segurança: Obstáculos pelo caminho e no tratamento de interrupção, há certo conflito de preferência entre pedestres e ciclistas.

Seu trecho final ocorre na altura do número 7500, próximo à Invernada da Polícia Militar. Conforme figura 22 abaixo.

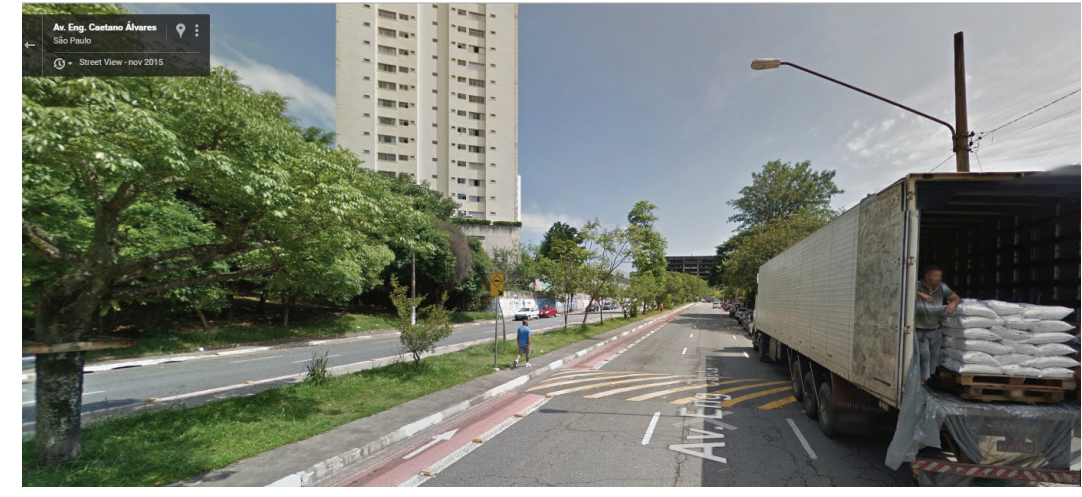

Figura 22 - Trecho final da Ciclovia da Avenida Engenheiro Caetano Álvares. Fonte: Google Maps. Acesso: 22/05/2016.

\section{CONCLUSÃO}

Analisando o traçado de alguns pontos da Avenida Engenheiro Caetano Álvares, é possível perceber algumas irregularidades no trajeto que podem causar desconforto, insegurança no ciclista. É verdade que a administração municipal tem se empenhado em aumentar a infraestrutura cicloviária e também, pudemos verificar que essa oferta, acabou por aumentar o uso da bicicleta de forma geral na cidade. No entanto, o esforço em conseguir bater a meta de quilometragem desta rede, não poderia ser maior que o cuidado no estabelecimento do traçado para assegurar a segurança do ciclista, 
bem como a coerência do sistema. Verificar a natural demanda por este tipo de modal e assegurar que o trajeto seja o mais seguro possível deveria ser mais importante do que conseguir entregar uma quantidade grande de ciclovias/ciclofaixas, cujo uso pode colocar o ciclista em perigo e também cujo trajeto não é amplamente utilizado, quer seja por falta de conexão do mesmo, quer seja pelos motivos já discutidos de falta de segurança.

Ainda, de acordo com o ITDP:

"A escala e a velocidade do processo de implantação das novas ciclovias e ciclofaixas entre 2014 e 2015 foram importantes para a constituição de traçados mínimos e permitiram o desenvolvimento de um conhecimento fundamental para a cidade de São Paulo, tanto em termos técnicos quanto das variáveis culturais, econômicas, políticas e de arranjos institucionais para lidar com o tema. O planejamento cicloviário deve se inspirar em exemplos consagrados em outras cidades e países, mas o olhar detalhado sobre as realidades e condições locais é um elemento fundamental.

É importante, no entanto, buscar o aperfeiçoamento das ações e da própria rede cicloviária. Se a redistribuição do espaço viário para contemplar a bicicleta foi fundamental neste primeiro momento, é preciso que a continuidade das ações busque também melhorar as características de qualidade da infraestrutura. A rede de ciclovias e ciclofaixas deve oferecer melhores condições de segurança, conforto, atratividade, linearidade e coerência para atrair ciclistas iniciantes, de todas as idades e com diferentes graus de aptidão para lidar com situações inesperadas.

Algumas falhas pontuais da rede se devem à escala das intervenções propostas para um curto período de tempo e podem ser facilmente corrigidas, outras têm como restrição o orçamento para obras mais complexas e outras esbarram em resistências de setores da sociedade com relação à redistribuição do espaço viário"(ITDP-Instituto de Políticas de Transporte e Desenvolvimento,2015)

Assim, vimos que é por demais importante que as ações da esfera administrativa continue no sentido de incentivar o uso da bicicleta. Também, é interessante que a sociedade como um todo se envolva em ações que visam a melhoria do sistema já 
implantado, para requerer cada vez mais qualidade aos quilômetros de ciclovias/ faixas que Ihes são entregues, pois quanto maior a quantidade de ciclistas, maior atenção os usuários de veículos motorizados terão, por conseguinte, menos inseguros serão os trajetos.

\section{REFERÊNCIAS BIBLIOGRÁFICAS}

BENEDICT, M. A.; MCMAHON, E. T. Green Infrastructure: Linking Landscapes and Communities. Washington: Island Press, 2006.

CET (Companhia de Engenharia de Tráfego). Ciclovias em São Paulo-Integrando e fazendo o bem para a cidade. Julho, 2014. São Paulo. Disponível em: < http://www. cetsp.com.br/media/316505/sp\%20400km_v2s.pdf>. Acesso em: 14/05/2016

Ciclocidade. Relatório de Contagem de Ciclistas- Inajar de Souza-2015. Disponível em <http://www.ciclocidade.org.br/noticias/772-relatorio-de-contagem-de-ciclistasinajar-de-souza-2015>. Acesso em :14/05/2016

FARR, Douglas. Urbanismo Sustentável: Desenho urbano com a Natureza. Porto Alegre: Bookman, 2013.

FRANCO, Maria de Assunção Ribeiro. Desenho Ambiental: Introdução à Arquitetura da Paisagem com o Paradigma Ecológico. São Paulo: Annablume, 1997.

GEHL, Jan, Cidades para Pessoas. Tradução Anita Di Marco, São Paulo. Ed: Perspectiva, 2013.

HANNES, Evy, BONDAR, Camila S. Infraestrutura verde para o bairro do Mandaqui: possibilidade ou utopia? Revista Labverde: FAUUSP. São Paulo, n.9, p.30-52, dez. 2014.

ITDP(Instituto de Políticas de Transporte e Desenvolvimento).Política de Mobilidade por Bicicletas e Rede Cicloviária da Cidade de São Paulo: Análise e Recomendações. Novembro, 2015.São Paulo. Disponível em: < http://itdpbrasil.org.br/politicacicloviaria-em-sao-paulo/>. Acesso em: 22/01/2016. 
MALATESTA, Maria Ermelina B. "A história dos estudos das bicicletas na CET".Boletim Técnico CET 50, São Paulo, 2012. 58p. Disponível em: < http://www.cetsp.com. br/media/135472/btcetsp50.pdf>. Acesso em: 20/05/2016.

MIRANDA, Antonio C.M, CITADIN, Larissa L. Bernardi, ALVES, Eduardo Valenga. "A importância das ciclofaixas na Reinserção da bicicleta no trânsito das grandes cidades". 17. . Congresso Brasileiro de Transporte e Trânsito. Curitiba, 2009. Disponível em: < http://www.antp.org.br/biblioteca>. Acesso em: 18/05/2016

Prefeitura de São Paulo. Plano de Mobilidade de São Paulo-Modo Bicicleta. São Paulo. [2015] Disponível em: < http://www.prefeitura.sp.gov.br/cidade/secretarias/ upload/chamadas/planmobsp-rev002_1428005731.pdf>. Acesso em: 14/05/2016.

RIBEIRO, Édelis Alves. "Sistema Cicloviário do Municipio de São Paulo". 18 $^{\circ}$.Congresso Brasileiro de Transporte e Trânsito. 20. 2011. p.117. Disponível em: < http:// www.antp.org.br/biblioteca>. Acesso em: 18/05/2016

Secretaria Executiva de Comunicação. Uso diário da bicicleta como meio transporte cresce $\mathbf{5 0 \%}$ em 2014. São Paulo, 2014. Disponível em: <http://www.capital.sp.gov. br/portal/noticia/3728 >. Acesso em: 14/05/2016

SP de bike. Disponível em: <http://www.cidadedesaopaulo.com/spdebike/ciclofaixasciclovias-ciclorotas>. 